\title{
Effects of Nitrogen Fertilization and Frequency of Cutting on the Yield and Composition of Pangola Grass in Puerto Rico'
}

\author{
José Vicente-Chandler, Jacinto Figarella, and Servando Silva ${ }^{2}$ \\ INTRODUCTION
}

Although Pangola is becoming one of the most popular pasture grasses of the Tropics there is little information on the effect of nitrogen fertilization or frequency of cutting on its productivity or composition. Oakes, et al. $(s)^{3}$ in the U.S. Virgin Islands, found that Pangola grass responded in yield, to increasing nitrogen rates up to 300 pounds per acre yearly, while Engibous, et al. (2), in Florida, found that this grass responded in yield to increasing nitrogen rates up to 320 pounds per acre yearly. Caro-Costas, et al. (1), in the mountain region of Puerto Rico, found that Pangola grass responded strongly in yield to nitrogen rates up to 400 pounds per acre yearly. They also found that lower yields were obtained when the forage was harvested by simulated grazing every 40 days, than by cutting every 60 days.

This paper presents the results of an experiment carried out to determine the response of Pangola grass to nitrogen fertilization as affected by frequency of cutting.

\section{MATERIALS AND METHODS}

The experiment was carried out at Río Piedras, over 2 consecutive years. The mean annual temperature is about $76^{\circ} \mathrm{F}$, with seasonal variations of less than $10^{\circ} \mathrm{T}$. Rainfall was 103.3 and 60.9 inches during the first and second years, respectively, representing close to record deviations from the long-time average of about 80 inches.

The soil is a Fajardo clay, a deep, red, fairly well-drained soil, on about a 20-percent slope. Initially, the surface 6 inches averaged 3.2 percent of organic matter, 0.17 percent of nitrogen, 12.1 m.e. exchange capacity, and 6.0 m.e. of exchangeable bases per $100 \mathrm{gm}$. of soil, and had a $\mathrm{pH}$ of 4.8 .

${ }^{1}$ This work was carried out cooperatively between the U.S. Department of Agriculture and the Agricultural Experiment Station of the University of Puerto Rico, Río Piedras, P.R.

${ }^{2}$ Project Supervisor, Soil Scientist, and Physical Science Technician (General), respectively, Soil and Water Conservation Research Division, Agricultural Research Service, U.S. Department of Agriculture.

${ }^{3}$ Italic numbers in parentheses refer to Iiterature Cited, p. 45. 
The treatments used were as follows:

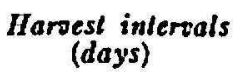

30

45

60

$\begin{gathered}\text { Nitrogen lecels } \\ \text { (pounds N per acre yearly) }\end{gathered}$
0
200
400
800
1,600

All combinations of these treatments were tested using a split-plot design, with harvest intervals as the main plots and nitrogen levels as the

TABLE 1.-Inches of rainfall by months during the 2 years of experimentation

\begin{tabular}{|c|c|c|c|}
\hline \multicolumn{2}{|c|}{ 1st year } & \multicolumn{2}{|c|}{ 2nd year } \\
\hline March 1958 & -6.4 & March 1959 & -2.2 \\
\hline April 1958 & -6.5 & April 1959 & -4.8 \\
\hline May 1958 & -20.2 & May 1959 & -8.4 \\
\hline June 1958 & -11.6 & June 1959 & -2.1 \\
\hline July 1958 & -8.3 & July 1959 & -7.9 \\
\hline August 1958 & -7.7 & August 1959 & -7.0 \\
\hline September 1958 & -14.9 & September 1959 & $-\mathbf{5 . 5}$ \\
\hline October 1958 & -8.1 & October 1959 & -9.0 \\
\hline November 1958 & $-\mathbf{0 . 5}$ & November 1959 & -4.6 \\
\hline December 1958 & -3.7 & December 1959 & -5.1 \\
\hline January 1959 & -6.8 & January 1960 & -.6 \\
\hline February 1959 & -2.6 & Febraury 1960 & -3.1 \\
\hline Total. . & 103.3 & Total. & .60 .9 \\
\hline
\end{tabular}

subplots. All treatments were replicated three times. Subplots were $10 \times 20$ feet, surrounded by ditches to prevent fertilizer from washing into adjoining plots.

The upper 6 inches of soil in all plots was limed to a $\mathrm{pH}$ of about 6.5 at the start of the experiment. Blanket additions of phosphorus and potassium were made at the rate of 300 pounds of $\mathrm{P}_{2} \mathrm{O}_{5}$ per acre from 20-percent superphosphate in 1 application, and 600 pounds $\mathrm{K}_{2} \mathrm{O}$ from $\mathrm{KCl}$ per acre annually in 6 to 12 equal applications, depending on frequency of cutting. The nitrogen was applied as ammonium sulfate in 6 to 12 equal applications yearly, depending on frequency of cutting.

The grass was cut at the prescribed intervals, weighed, and the forage removed from the plots. Samples from each plot at every harvest were analyzed for dry matter and total nitrogen. The crude-protein content was calculated using the factor 6.25 times $\mathrm{N}$. Samples were composited 
by plots at the end of the second year and analyzed for calcium, phosphorus, potassium, and lignin.

\section{RESULTS}

Table 1 shows the rainfall distribution by months during the 2-year course of the experiment.

TABLE 2.-The effects of nitrogen fertilization and frequency of cutting on the yield and protein content of Pangola grass and on the efficiency of utilization of the applied nitrogen over a 2-year period

\begin{tabular}{l|c|c|c|c|c|c|c}
\hline $\begin{array}{c}\text { Nitrogen } \\
\text { (pounds) }\end{array}$ & $\begin{array}{c}\text { Yield of green } \\
\text { forage per } \\
\text { acre yearly }\end{array}$ & $\begin{array}{c}\text { Dry- } \\
\text { matter } \\
\text { content }\end{array}$ & $\begin{array}{l}\text { Yield of dry } \\
\text { matter per } \\
\text { acre yearly }\end{array}$ & $\begin{array}{c}\text { Crude- } \\
\text { protein } \\
\text { content }\end{array}$ & $\begin{array}{c}\text { Crude- } \\
\text { protein } \\
\text { yield per } \\
\text { acre yearly }\end{array}$ & $\begin{array}{c}\text { Recovery } \\
\text { of N in } \\
\text { forage }\end{array}$ & $\begin{array}{c}\text { Dryaduced per } \\
\text { pound of each } \\
\text { increment } \\
\text { of } N\end{array}$ \\
\hline
\end{tabular}

Grass cut every 30 days

\begin{tabular}{r|c|c|c|c|c|c|c}
\hline & $L b$. & Percent & Lb. & Percent & $L b$. & Percent & $L b$. \\
0 & 47,752 & 20.2 & 9,650 & 8.0 & 773 & - & - \\
200 & 100,688 & 16.3 & 16,414 & 10.2 & 1,677 & 72.3 & 33.8 \\
400 & 126,064 & 15.3 & 19,260 & 12.5 & 2,400 & 65.1 & 14.2 \\
800 & 130,960 & 15.1 & 19,785 & 14.3 & 2,833 & 41.2 & 1.3 \\
1,600 & 125,599 & 15.2 & 19,148 & 15.0 & 2,862 & 20.8 & - \\
\hline
\end{tabular}

Grass cul every 45 days

\begin{tabular}{r|r|r|r|r|r|r|r}
\hline 0 & 40,599 & 20.8 & 8,430 & 6.3 & 530 & - & - \\
200 & 101,756 & 17.4 & 17,727 & 8.1 & 1,427 & 71.8 & 46.5 \\
400 & 136,577 & 16.8 & 22,899 & 9.6 & 2,201 & 66.9 & 25.9 \\
800 & 140,570 & 16.8 & 23,607 & 11.7 & 2,764 & 44.7 & 1.8 \\
1,600 & 121,947 & 16.9 & 20,585 & 13.0 & 2,679 & 21.5 & - \\
\hline
\end{tabular}

Grass cut every 60 days

\begin{tabular}{r|r|r|r|r|r|r|r}
\hline 0 & 50,440 & 23.7 & 11,955 & 5.5 & 652 & - & - \\
200 & 115,957 & 22.3 & 25,871 & 5.8 & 1,512 & 68.8 & $\mathbf{6 9 . 6}$ \\
400 & 146,889 & 20.3 & 29,762 & 8.0 & 2,366 & $\mathbf{6 8 . 6}$ & 19.5 \\
800 & 165,958 & 18.7 & 30,987 & 10.8 & 3,344 & 53.8 & 3.1 \\
1,600 & 153,850 & 18.6 & 28,688 & 12.0 & 3,429 & 21.5 & - \\
\hline
\end{tabular}

\section{EFFECT OF LENGTH OF HARVEST INTERVAL}

The data in table 2 and figure 1 show that yields increased markedly with length of harvest interval, particularly that from 45 to 60 days. At the 400-pound level of nitrogen, Pangola grass produced 19,260, 22,899, and 29,762 pounds of dry matter per acre yearly when cut at 30-, $45-$, and 60-day intervals, respectively. The dry-matter content of the forage also 
increased with harvest intervals, averaging $15.3,16.8$, and 20.3 percent for these cutting intervals, respectively.

Figure 2 shows that, at nitrogen rates of 800 pounds or less, yields were similar during both years with a 60-day harvest interval. However with a 45-day harvest interval much lower annual yields were produced during the second, drier year. This may be explained by better root development with the 60-day interval enabling the grass to make full use during dry periods of moisture stored in the soil. Yields were similar over periods of

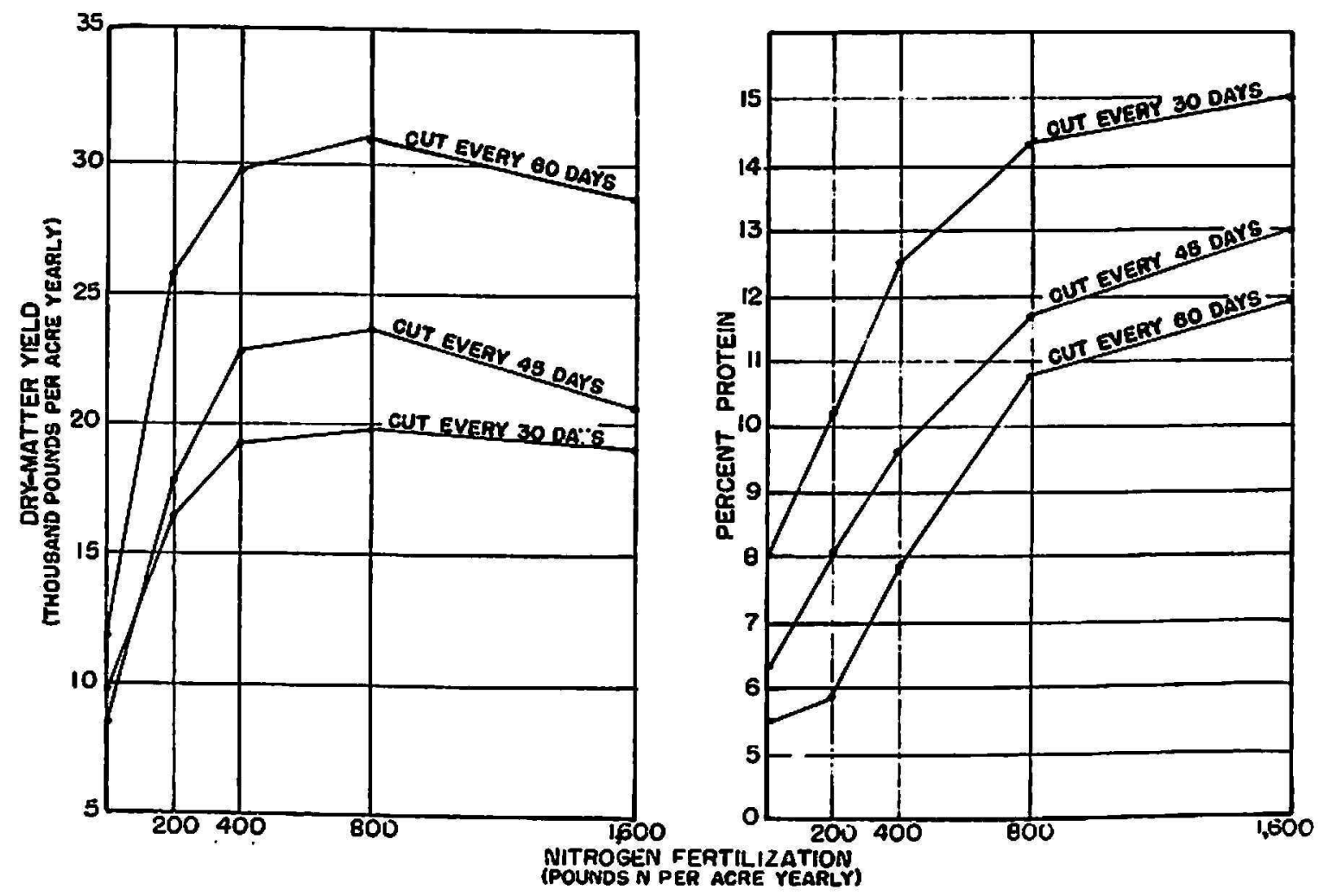

Fig. 1.-Effects of nitrogen fertilization and frequency of cutting on yields and protein content of Pangola grass.

adequate rainfall in both years with the 45-day interval, showing that production was not diminishing with age of the pasture. These results suggest the desirability of using a longer harvest interval during unfavorable seasons and a shorter one during good weather.

The protein content of the forage dropped with each increase in harvest interval averaging, at the 400-pound level of nitrogen, 12.5, 9.6, and 8.0 percent when the grass was cut at $30-, 45-$, and 60-day intervals, respectively.

The proportion of applied nitrogen recovered in the forage was not appreciably affected by length of harvest interval.

The data in table 3 show that the phosphorus, potassium, and calcium 
contents of Pangola grass tended to decrease slightly while the lignin contents increased slightly with length of harvest interval.

\section{EFFECT OF NITROGEN FERTILIZATION}

The data in table 2 and figure 1 show that yields increased rapidly with nitrogen fertilization up to the 400-pound level at all harvest intervals. With a 45-day harvest interval, yields were almost tripled to 22,899

A

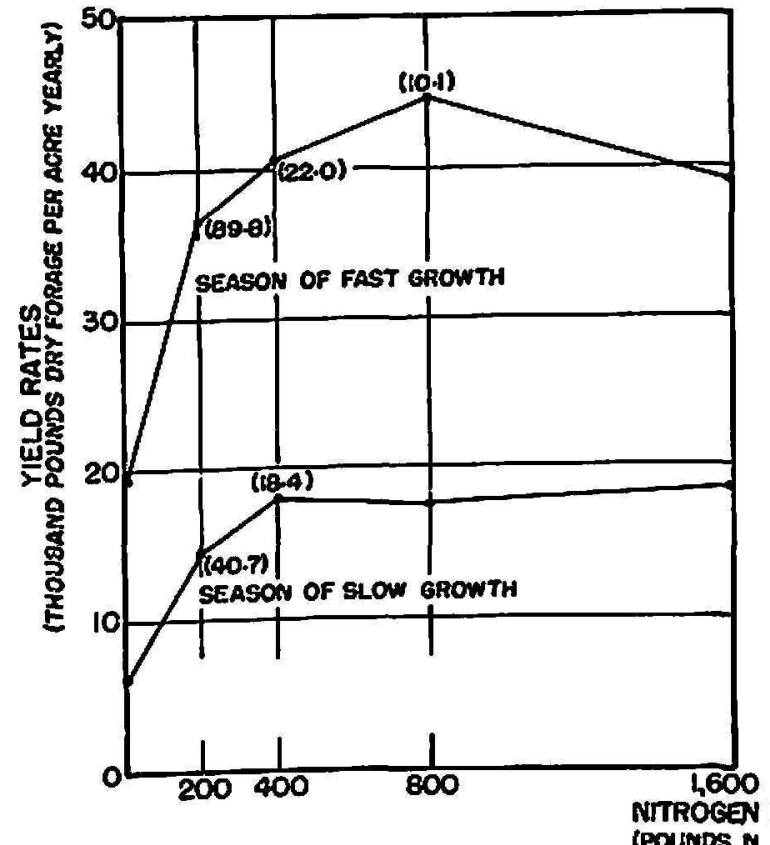

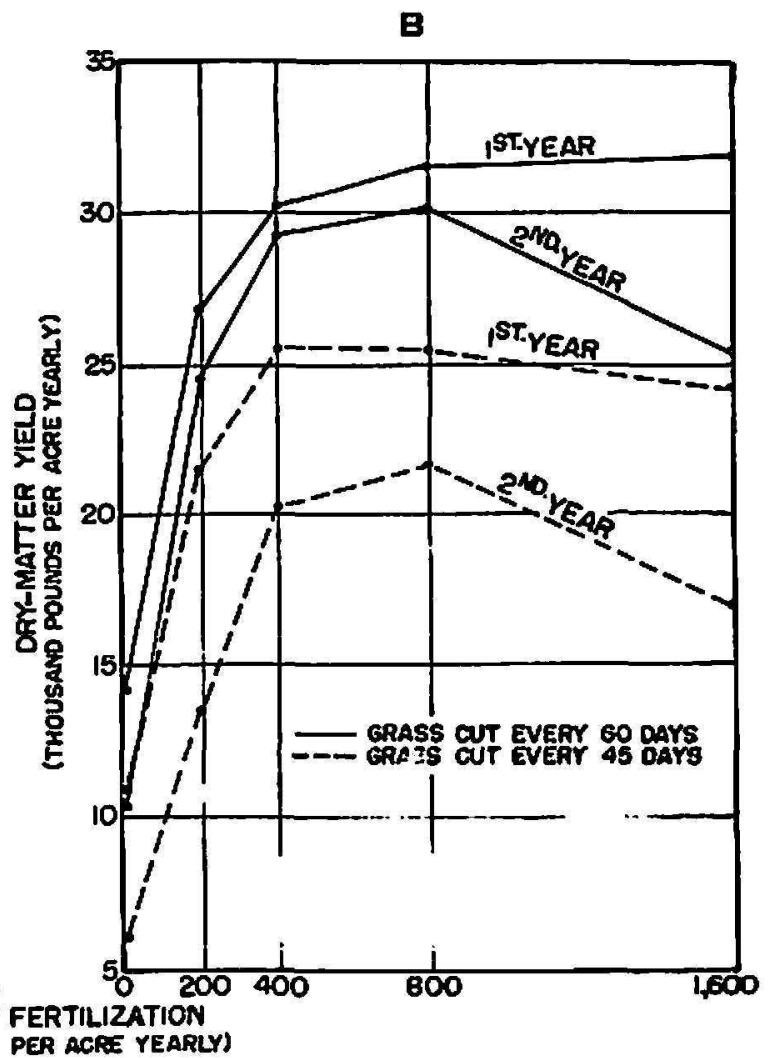

FIG. 2.-Effect of season of the year (A) and years with widely different rainfall (B) on the response of Pangola grass to nitrogen fertilization. In A, numbers in parentheses show pounds of dry forage per pound increment of $N$; in $B$, rainfall was 103.3 inches the first year and 60.9 inches the second.

pounds of dry forage per acre yearly by the application of 400 pounds of nitrogen.

Figure 2 shows that despite the sharp difference in yields between seasons of slow (January-Mareh) and of fast growth, Pangola grass responded strongly to the 400-pound nitrogen rate at all times of the year. This figure also shows a strong response to the 400-pound $\mathrm{N}$ rate during both years despite the wide difference in rainfall. Yields decreased during the much drier second year when 1,600 pounds of nitrogen were applied due to damage by burning.

The protein content of the forage increased with nitrogen rates up to 
the highest level tested averaging, when cut every 45 days, $6.3,8.1,9.6$, 11.7 , and 13.0 percent when fertilized with $0,200,400,800,1,600$ pounds of nitrogen per acre yearly, respectively. The highest protein content of 15.0 percent was attained with a 30 -day harvest interval and 1,600 pounds

TABLE 3.-The effects of nitrogen fertilization and harvest interval on the composition of Pangola grass expressed as percentage on a dry-weight basis

\begin{tabular}{|c|c|c|c|c|}
\hline \multirow{2}{*}{$\begin{array}{l}\text { Nitrogen fertilization (pounds } \\
\text { N per acre yearly) }\end{array}$} & \multicolumn{4}{|c|}{ Results at harvest interval indicated } \\
\hline & 30 days & 45 days & 60 days & Average \\
\hline \multicolumn{5}{|c|}{ Phosphorus } \\
\hline $\begin{array}{l}400 \\
800\end{array}$ & $\begin{array}{r}0.22 \\
.19\end{array}$ & $\begin{array}{r}0.22 \\
.18\end{array}$ & $\begin{array}{r}0.18 \\
.14\end{array}$ & $\begin{array}{r}0.21 \\
.17\end{array}$ \\
\hline Average & 0.21 & 0.20 & 0.16 & 0.19 \\
\hline \multicolumn{5}{|c|}{ Calcium } \\
\hline $\begin{array}{l}400 \\
800\end{array}$ & $\begin{array}{r}0.43 \\
.42\end{array}$ & $\begin{array}{r}0.36 \\
.43\end{array}$ & $\begin{array}{r}0.34 \\
.41\end{array}$ & $\begin{array}{r}0.38 \\
.42\end{array}$ \\
\hline Average & 0.42 & 0.39 & 0.37 & 0.40 \\
\hline \multicolumn{5}{|c|}{ Polassium } \\
\hline $\begin{array}{l}400 \\
800\end{array}$ & $\begin{array}{l}2.6 \\
2.3\end{array}$ & $\begin{array}{l}2.3 \\
2.1\end{array}$ & $\begin{array}{l}1.8 \\
1.6\end{array}$ & $\begin{array}{l}2.2 \\
2.0\end{array}$ \\
\hline Average & 2.4 & 2.2 & 1.7 & 2.1 \\
\hline \multicolumn{5}{|c|}{ Lignin } \\
\hline $\begin{array}{l}400 \\
800\end{array}$ & $\begin{array}{l}8.1 \\
8.4\end{array}$ & $\begin{array}{l}8.8 \\
8.5\end{array}$ & $\begin{array}{l}9.2 \\
9.7\end{array}$ & $\begin{array}{l}8.7 \\
8.8\end{array}$ \\
\hline Average & 8.2 & 8.6 & 9.4 & 8.7 \\
\hline
\end{tabular}

of nitrogen per acre yearly. The nature of the curve in figure 1 indicates that this is probably close to the maximum protein content attainable with this grass when using a 30-day harvest interval. The assumption is made that the nitrogen was essentially all in the amino form since no more than traces of nitrates were found in the forage.

Protein yields increased rapidly with nitrogen fertilization up to the 800-pound level averaging, with a 45-day harvest interval, 530, 2,201, 
and 2,764 pounds per acre yearly at the $0-.400-$, and 800-pound levels of nitrogen, respectively.

The data in table 2 show that from about 65 to 72 percent of the applied nitrogen was recovered in the forage when 400 pounds or less were applied per acre yearly. Percentage recovery decreased with increasing rates above 400 pounds. Pangola grass obtained about 100 pounds of nitrogen per acre yearly from the soil when none was applied as fertilizer.

The efficiency of utilization of fertilizer nitrogen decreased rapidly with increasing rates. With a 45-day harvest interval, 46.5, 25.9, 1.8, and 0 pounds of dry matter were produced per pound of each successive increment of nitrogen.

Figure 2 shows that more dry forage was produced per pound of nitrogen during seasons of flush than during seasons of slow growth. Also, only 41.2 percent of the 400-pound nitrogen application was recovered in the forage during seasons of slow growth, compared to 89.0 percent during seasons of flush growth.

The data in table 3 show that the phosphorus content of the forage decreased slightly with increased nitrogen fertilization, while lignin, potassium, and calcium contents were not apparently affected by fertilization. The data in table 2 show that dry-matter content of the forage decreased slightly with increasing nitrogen rates.

\section{EFFECT OF SEASON OF THE YEAR}

It is remarkable that yields were so similar (fig. 2) during both years despite a difference in rainfall of more than 40 inches.

Season of the year, however, had a marked effect on yields. During January and February of both years, Pangola grass receiving 400 pounds of nitrogen per acre yearly and cut every 60 days produced at the rate of only about 17,000 pounds of dry forage per acre yearly, compared to an average rate of about 33,000 pounds for the remainder of the year.

Protein content of the forage also varied considerably with season of the year ranging, with a 45 -day harvest interval and 400 pounds of nitrogen, from as low as 6.7 to as high as $\mathbf{1 4 . 9}$ percent. In general, protein content was highest during seasons of slow growth and vice versa.

\section{DISCUSSION}

Highest yields were obtained when Pangola grass was cut every 60 days, but the forage was of lower quality as indicated by a higher lignin and lower protein content. It is probably best to harvest. Pangola grass about every 45 days, during seasons of fast growth and about every 60 days during the season of slow growth. Pangola grass pastures may be grazed as often as every 25 days during periods of fast growth. 
The application of 400 pounds of nitrogen per acre yearly to Pangola grass was apparently warranted with all harvest intervals under the conditions of this experiment.

With a 60-day harvest interval and 400 pounds of nitrogen per acre yearly, Pangola grass produced about 73 tons of green forage, or 29,762 pounds of dry matter with 8.0 percent of protein per acre yearly. This is sufficient to meet the roughage requirements of about four mature cows.

With proper management, yields of this magnitude can be obtained under widely different soil and climatic conditions found on the Island, provided moisture is adequate. For example, in experiments by CaroCostas, et al. (1), properly managed Pangola grass yielded 23,207 pounds of dry matter per acre yearly on a steep Catalina clay in the mountain region. Nearby experimental Pangola grass pastures properly managed and heavily fertilized, yielded 900 pounds of gains in weight and 6,379 pounds of total digestible nutrients per acre yearly.

\section{SUMMARY}

The effects of nitrogen rates ranging from 0 to 1,600 pounds of $N$ per acre yearly and of 30-, 45-, and 60-day harvest intervals on the yield and composition of Pangola grass were determined for 2 consecutive years.

Yields increased sharply with nitrogen fertilization up to the 400 -pound level, while protein content increased up to the 1,600-pound level. About two-thirds of the fertilizer nitrogen was recovered in the forage when 400 pounds or less were applied per acre yearly. Efficiency of utilization, in terms of dry matter produced per pound of nitrogen, decreased with increasing rates.

Yields and lignin content of the forage increased while the protein content decreased with length of harvest interval.

A 45-day harvest interval during seasons of flush growth, and a 60-day interval during the season of slow growth, combined with 400 pounds of nitrogen per acre yearly seems to be the optimum combination. Yields varied widely with season of the year.

\section{RESUMEN}

Se estudió el efecto de aplicaciones de nitrógeno que variaban entre 0 y 1,600 libras por cuerda por año, y de intervalos de corte de 30,45 , y 60 días, en el rendimiento y composición de la yerba Pangola (Digilaria decumbens).

Los rendimientos aumentaron con niveles de nitrógeno hasta 400 libras por cuerda por año. Fl contenido de proteína aumentó con niveles de nitrógeno hasta 1,600 libras por cuerda por año. Se recuperó aproximadamente en el forraje las dos terceras partes del nitrógeno aplicado hasta 
400 libras por cuerda. La eficiencia de utilización expresada en términos de forraje seco producido por cada libra de nitrógeno disminuyó según se aumentaban los niveles de nitrógeno.

Los rendimientos de forraje seco y el contenido de lignina aumentaron, pero el contenido de proteína disminuyó según se alargaron los intervalos de corte.

Un intervalo de corte de $45-60$ días y 400 libras de nitrógeno por cuerda por año parece ser el tratamiento óptimo.

La producción varió considerablemente durante las distintas épocas del año.

\section{LITERATURE CITED}

1. Caro-Costas, R., Vicente-Chandler, J., and Figarella, J., The yield and composition of five grasses growing in the humid mountains of Puerto Rico as affected by nitrogen fertilization, season, and harvest procedure, J. Agr. Univ. P.R. $44(1), 1961$.

2. Engibous, J. C., Friedmann, Jr., W. J., and Gillis, M. B., Yield and quality of Pangola grass and Bahia grass, as affected by rate and frequency of fertilization, Soil Sci. Soc. Amer. Proc. $22(5)$ 423-5, 1958.

3. Oakes, A. J., Bond, R. M., and Skov, O., Pangola grass in the United States Virgin Islands, Trop. Agr. 36 130-7, 1959. 